\title{
Circular Business Models for Remanufacturing in the Electric Bicycle Industry
}

\author{
Carina Koop ${ }^{1 *}$, Julian Grosse Erdmann ${ }^{2}$, Jan Koller ${ }^{2,3}$ and Frank Döpper ${ }^{2,3}$ \\ ${ }^{1}$ Wuppertal Institute for Climate, Environment and Energy, Wuppertal, Germany, ${ }^{2}$ Fraunhofer Institute for Manufacturing \\ Engineering and Automation IPA, Project Group Process Innovation, Bayreuth, Germany, ${ }^{3}$ Chair Manufacturing and \\ Remanufacturing Technology, University of Bayreuth, Bayreuth, Germany
}

\section{OPEN ACCESS}

Edited by:

Simone Sehnem,

University of West of Santa

Catarina, Brazil

Reviewed by:

Alessandro Annarelli,

Sapienza University of Rome, Italy

Wiebke Reim,

Luleå University of

Technology, Sweden

*Correspondence:

Carina Koop

carina.koop@wupperinst.org

Specialty section: This article was submitted to

Circular Economy,

a section of the journal

Frontiers in Sustainability

Received: 28 September 2021 Accepted: 04 November 2021

Published: 01 December 2021

Citation:

Koop C, Grosse Erdmann J, Koller J and Döpper F (2021) Circular

Business Models for Remanufacturing in the Electric Bicycle Industry.

Front. Sustain. 2:785036.

doi: 10.3389/frsus.2021.785036
The rising popularity and strong increase in the number of electric bicycles make it necessary to consider the built-in resources as well as possible treatments after the use phase. The time lag between the purchase and the occurrence of relevant defects suggests significant increases in defective components. Especially the great dynamics of the market due to regular innovations, product renewals, and the lack of spare parts availability for older models make the long-term use by customers much more difficult than for conventional bicycles. Therefore, it is necessary to analyze circular business models for the electric bicycle market. In this way, the required structures for a sustainable electric bicycle industry can be created so that valuable materials do not go into disposal but undergo a new use phase. Based on the results of "AddRE-Mo-Value Preservation Scenarios for Urban Electromobility of Persons and Loads through Additive Manufacturing and Remanufacturing," a research project funded by the German Federal Ministry of Education and Research, this paper addresses four circular business models, two sales models, and two service models. The guiding research interest of this paper is the combination of remanufacturing and additive manufacturing from a business model perspective, analyzing the extent to which additive remanufacturing can be considered a solution for electric bicycles' circularity. After describing the approach and methods used to develop these four circular business models the business models are described and analyzed using the Business Model Canvas. Based on this analysis, it is shown that the combination of remanufacturing and additive manufacturing can be applied to the electric bicycle market and be integrated into both sales and service models. The description of these business models will help managers design viable business models in the context of sustainable electric bicycles. It also shows that the individual partners within the value chain must collaborate more closely. In the electric bicycle industry, a single company will probably not be able to close the product cycle completely. Further research is needed to develop concepts of the business models and examine their practical feasibility in technical and organizational operations to achieve a circular economy.

Keywords: circular economy, additive manufacturing, closed-loop, leasing, product-service system, mass customization 


\section{INTRODUCTION}

The transformation of the mobility sector is being discussed more and more frequently, with innovative mobility concepts playing an important role. Electric bicycles, whose image was once regarded critically, have become increasingly popular in recent years. In 2020, 1.95 million electric bicycles were sold in Germany, representing a $43.4 \%$ growth in sales compared to 2019. The share of electric bicycles in total sales of the bicycle industry was therefore $38.7 \%$ (Zweirad-Industrie-Verband, 2021). Due to the increasing importance of electric mobility, the number of resources used per bicycle (e.g., energy, material) plays a central role in the sustainable market development of the electric bicycle industry (Amrhein, 2017). Amrhein (2017) shows that during production, use, and especially after the end of use phase, no well-elaborated circular concepts for the components and raw materials contained in electric bicycles exist. Especially the great dynamics of the market due to regular innovations, product renewals, and the lack of spare parts availability for older models make the long-term use by customers much more difficult compared to conventional bicycles (Koop et al., 2021). Therefore, it is necessary to analyze circular business models for the electric bicycle market. In this way, the necessary structures for a sustainable electric bicycle industry can already be created so that the valuable materials do not go into disposal but undergo a new use phase. On the one hand, for the electric bicycles already on the market, it is necessary to consider how they can be taken back and reused, remanufactured, or recycled. On the other hand, for electric bicycles to enter the market in the future, a circular business model should be chosen from the beginning. Thereby, the return and further use can be taken into account already in the product development. For this purpose, four circular business models are presented in this paper that can support the circularity of electric bicycles. According to Nußholz (2017) a circular business model is the way a company creates and captures value with a value creation focused on improving resource efficiency by contributing to extending the useful life of products and parts (e.g., through durable design, repair, and remanufacturing) and closing material loop. Combining additive manufacturing and remanufacturing in a joint approach could be a solution to close the loop of electric bicycles.

Following the state of the art review and description of the research gap, the paper is embedded in its methodological background. Therefore, the approach and method used to develop four circular business models are described. In the next section, these business models are analyzed and described using the Business Model Canvas. Based on the analysis, a conclusion of the paper is provided, and the key findings are briefly discussed. In addition, an outlook is provided for further potential research projects.

\section{STATE OF THE ART}

Remanufacturing closes product life cycles and thus enables the reuse of cores (used products being the raw material of the remanufacturing process) at the end of their useful life (Walther, 2010; Westkämper and Warnecke, 2010). In contrast to the manual repair of defective products, remanufacturing represents an industrial process. The remanufactured product is restored to an as-good-as-new condition (Steinhilper, 1999; British Standards Institution, 2009). Remanufacturing can also offer an opportunity to extend the life of components (Russell and Nasr, 2020). Research on remanufacturing as a circular business model is already well-established (see e.g., Chierici and Copani, 2016; Steeneck and Sarin, 2018; Bag et al., 2019; Russell and Nasr, 2020). There are also approaches in the mobility sector focusing on remanufacturing, which are mainly established in the automotive aftermarket. Components such as engines, transmissions, and alternators are remanufactured in closedloop systems (Parker et al., 2015). In contrast, there has been very little research into analogous strategies for remanufacturing (electric) bicycles.

Additive manufacturing can represent a potential solution approach in the remanufacturing of electric bicycles. Additive manufacturing is a manufacturing process in which components are created by adding material layer by layer or by phase transition of a material from the liquid or powder state to the solid-state (Verein Deutscher Ingenieure, 2014). One advantage is the elimination of product-dependent set-up times and production preparations in additive manufacturing, which allows production that is almost independent of batch size and thus also the cost-efficient production of individual pieces (batch size one) or small series. Furthermore, the unit costs of additive manufactured components are independent of the component complexity compared to conventional manufacturing processes (Lachmayer et al., 2018). The direct production of a physical component from a 3D CAD file also makes it possible to produce components according to demand and digitally store the data instead of spare parts (Rieg and Steinhilper, 2018). Combining these advantages enables decentralized and demand-oriented production, which will permanently change existing value systems. The main application areas for additive manufacturing arise, particularly in prototype construction, toolmaking, and the manufacture of end products and spare parts (Gebhardt, 2016). In this context, using additive manufacturing to replace parts that are not suitable for remanufacturing is defined as additive remanufacturing (Kleylein-Feuerstein, 2020). The critical aspects of a spare parts supply chain can be solved using additive manufacturing (Dircksen and Feldmann, 2020). The potential of additive manufacturing processes in the circular economy is known (Ford and Despeisse, 2016; Rieg and Steinhilper, 2018). However, it is not yet established, though it is still in the early stages of research (Kohlhuber et al., 2016).

A holistic view of the electric bicycle, which is missing in the current state of research, is necessary in order to be able to sustainably close product cycles of urban electromobility under economic, ecological, and social interests. This paper fills the research gap by analyzing how electric bicycles can be designed and used in a circular way. The purpose of the study is to identify opportunities for the circularity of electric bicycles by combining additive manufacturing and remanufacturing in a joint approach. Especially for the combination of remanufacturing and additive manufacturing, further research is needed (Matsumoto et al., 2016). This article analyses the extent 
to which remanufacturing can be considered as a solution for the circularity of electric bicycles and shows the potential of different circular business models combining remanufacturing with additive manufacturing. To the best of our knowledge, this is the first work that deals with different possible business models in the field of additive remanufacturing of electric bicycles.

\section{METHOD}

According to Magretta (2002), business models describe how the components of a business fit together as a system. There are different approaches regarding the definition of which exact components make up a business model. The components can, however, generally be summarized into four core elements. The names and subdivisions can vary depending on the literature (see e.g., Geissdoerfer et al., 2018 for an overview of different definitions) (Frankenberger et al., 2013; Gassmann et al., 2013; Schulz et al., 2018). According to Gassmann et al. (2013), the core elements are: value proposition, value chain (activities, resources and network), revenue model, and target customer (segment). This framework, which is common in research, also builds the foundation of the 55 business model patterns, which were identified by analyzing 250 business models along those four dimensions of the framework (Böhm et al., 2017). Besides the value proposition, the elements describe a company's value creation, value capture, and value delivery (Günzel and Holm, 2013). The elements can be visualized as a "magic triangle," with the target customer (segment) being at the center since the optimization of one of the corner elements automatically requests adoption of the other corner elements (Gassmann et al., 2013; Steinhöfel et al., 2016). Figure 1 shows the four elements, including their associated questions, on which basis business models can be concretized and illustrated. Giving a detailed view of the four elements makes a business model comprehensible and provides the basis for its innovation (Schulz et al., 2018).

Various procedure models exist in the literature to support the development of new (circular) business models (Steinhöfel et al., 2016; Bocken et al., 2019). Due to interdependent elements and

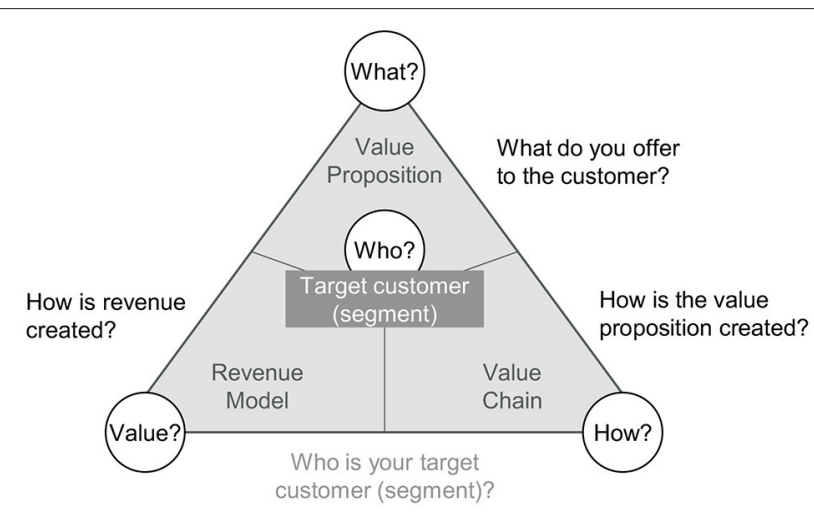

FIGURE 1 | Magic triangle and the four elements of a business model, based on Gassmann et al. (2013). their different manifestations that need to be taken into account, the development of a business model is unique and must be considered on a case-by-case basis (Osterwalder et al., 2010). In addition, further distinctions can be made, whether the aim is to expand an existing business model or develop a new one and to which degree a business model transformation toward sustainability will be implemented (Gauthier and Gilomen, 2016; Geissdoerfer et al., 2020). The applied procedure for this work is based on the work of Feldmann (2018), who initially developed this procedure model for business model innovations through additive manufacturing. The adapted systematic procedure consists of five successive steps from analysis to implementation of a business model, as shown in Figure 2. In the following, the individual steps and their aims are described in detail.

\section{Analysis}

The starting point is an analysis of stakeholders and influencing factors of the business ecosystem for electric bicycles in Germany to understand the business environment. In addition to classic market and literature research, three surveys were conducted with users, electric bicycle workshops, and experts in the electric bicycle sector from research and industry. The results of this analysis have been summarized in a separate study (Häfner et al., 2021).

The user survey was conducted via an online questionnaire, which more than 500 participants completed. In addition to socio-demographic data, questions were asked in particular about the use of transport, personal attitudes toward electric bicycles, and their perceived sustainability, as well as alternatives to the purchase of electric bicycles. An important aspect in establishing a market for remanufactured electric bicycle components is the acceptance and the demand of these products by users. The survey showed a broad acceptance of the remanufactured electric bicycle components. More than $80 \%$ of the respondents stated that there is interest or a high interest in using remanufactured electric bicycle components.

In addition, 45 workshops for electric bicycles were surveyed. The online survey focused on the market development forecast, damages, repair options, and the disposal of electric bicycle components. Furthermore, the knowledge and use of additive manufacturing and remanufacturing and potentially suitable components were inquired. According to the workshops, motor and accumulator of electric bicycles show the greatest potential for remanufacturing. This is due to their high value, the importance regarding the operability of electric bicycles, and the frequency of defects.

In a third survey, telephone interviews were conducted with 15 experts from different areas of the electric bicycle industry (e.g., suppliers, manufacturers, associations, and federations). The experts' statements were used to analyze, confirm or, if necessary, critically question the statements and forecasts made by users and workshops. The experts were also asked about the applicability of additive manufacturing and remanufacturing for electric bicycles and future forecasts regarding market and technology development. The majority of experts do not see a conflict between the development and production of 


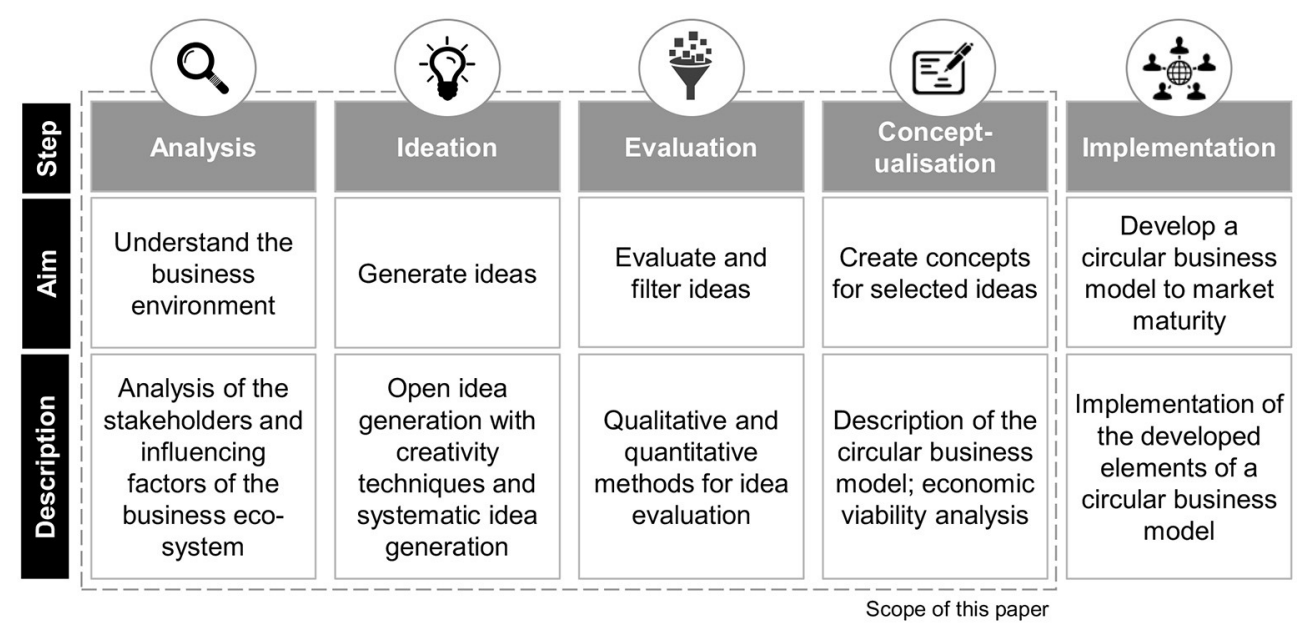

FIGURE 2 | Procedure model from analysis to implementation of business models, based on Feldmann et al. (2019).

durable products and a high speed of innovation in the electric bicycle sector.

In general, it can be concluded that the demand for electric bicycles in Germany will increase in the next years. A market share of electric bicycles of more than $50 \%$ of the total bicycle market seems likely. In particular, the relatively high proportion of users (almost one-third) who can imagine buying an electric bicycle in the next 5 years shows the existing potential of this market and the importance of establishing circular business models.

\section{Ideation}

Based on the preceding analysis, the next step is to develop ideas for both innovative and circular business models in the electric bicycle industry. The focus is on business models that allow remanufacturing of electric bicycles at the end of the product's life. Furthermore, the focus is not only on pure sales models but also on product-service systems. In general, productservice system business models allow companies to create new sources of added value and competitiveness while at the same time fostering sustainability (Tukker, 2004, 2015). According to Zweirad-Industrie-Verband (2021), a product-service system can be defined as a "marketable set of products and services capable of jointly fulfilling a user's need" (Goedkoop et al., 1999). In general, three main categories of product-service systems can be distinguished (Tukker, 2004):

- Product-oriented services: The business model is still mainly focused on selling products but additional services are offered.

- Use-oriented services: The business model is not focused on selling products; however, the product still plays a key role. It remains property of the provider, is made available in different forms and sometimes shared by a number of users.

- Result-oriented services: The business model is focused on an outcome that both customer and provider agree on. There is no pre-determined product involved.
The ideation is an essential step toward business model innovations and aims to open up the solution space and generate a set of possible business models (Frankenberger et al., 2013; Mansuy et al., 2021). Therefore, as many ideas for new business models as possible are developed during ideation, whereas their evaluation follows in the next step.

In a workshop, the project consortium used creativity techniques such as brainstorming to generate initial ideas for possible business model innovations. The applied creativity techniques led to initial ideas that offer possible approaches to business model innovation. A greater challenge, however, is the transfer of an initial idea into a new business model. This can be reasoned, for example, by a too vague value proposition for the customer or by the abstract thinking process in business models causing problems for those involved (Feldmann et al., 2019). Therefore, business model patterns were applied to support the ideation process to encourage thinking in terms of business models instead of technologies, products, and processes (Feldmann et al., 2019). Thereby, the Business Model Navigator, a catalog of 55 different business models, which can be adapted to form an individual business model, served as a basis (Gassmann et al., 2021).

\section{Evaluation}

After generating ideas for circular business models focusing on the remanufacturing of electric bicycles, they are evaluated in the next step. The evaluation of ideas aims to increase the probability of economic success of an innovative idea, respectively, a business model innovation, and minimize the risk of failure (von Ahsen et al., 2010). The evaluation selects the most promising ideas from the multitude of alternatives since resource constraints do not allow all ideas to be implemented (Disselkamp, 2005; Kock et al., 2015). Therefore, the individual business model innovations are evaluated and ranked in terms of their marketability and economic viability or, respectively, in terms of opportunities and risks (von Ahsen et al., 2010). The aim is to identify business model ideas with, e.g., high market potential or low 
use of resources (Disselkamp, 2005; Feldmann et al., 2019). The evaluation was carried out as a two-stage filtering process (Feldmann et al., 2019). Because an evaluation of all alternatives would represent an unreasonably high effort, e.g., the necessary gathering of information, a rough selection was made in the first selection stage. Therefore, the project consortium based the first selection of business models on easily verifiable criteria using a scoring method (Stern and Jaberg, 2007; Feldmann et al., 2019). In the second stage, a ranking was established by means of a positive selection, and the best ideas were selected for a detailed analysis.

Thereby, the evaluation process focused on two circular business models, access and performance models and sales models designed to extend product value and determine which circular business models are suitable for remanufacturing electric bicycles. These circular business models transform electric bicycles' linear product life cycle into closed product cycles through additive manufacturing and remanufacturing. In addition to quantitative methods such as profitability calculations, the evaluation of these business models also identified the motivation for implementing the business model, potentials for the circular economy, and challenges for development or implementation. Four potential business models for remanufacturing electric bicycles in combination with additive manufacturing were identified during the evaluation process.

\section{Conceptualization}

In the next step, the selected ideas for circular business models are transformed into a concrete concept. The conceptualization can be supported by using tools to visually represent the business model innovation (Täuscher and Abdelkafi, 2017). A proven method to systematically describe business models is the Business Model Canvas by Osterwalder et al. (2010). It is based on the work of Osterwalder on business model ontologies (Osterwalder, 2004). The Business Model Canvas is widely used in research and industry and has been successfully implemented in many companies, e.g., IBM, Ericsson, and Deloitte (Barquet et al., 2013; Joyce and Paquin, 2016).

The core of the Business Model Canvas is nine building blocks that serve as the basis for describing the four main elements of a business model (Osterwalder et al., 2010; Gassmann et al., 2013). These interrelated building blocks are listed and described in Table 1.

The relationship between the building blocks of the Business Model Canvas and the elements of a business model can be outlined as follows (Osterwalder et al., 2010; Gassmann et al., 2013): the value proposition forms the center of the Business Model Canvas, as the core of a business model. The value proposition is created through the value chain, which comprises key partners, key activities and resources of the Business Model Canvas. The target customer (segment), a company aims to reach is described by the building blocks Key Partners, Key Activities, and Key Resources. At the bottom of the Business Model Canvas, the revenue model is shown in the form of the Cost Structure and the Revenue Streams. The profit is calculated by subtracting the total costs from the sum of all revenue streams
TABLE 1 | Building blocks of the business model canvas and their description, based on Osterwalder et al. (2010, 2014), Barquet et al. (2013), Lewandowski (2016).

\begin{tabular}{|c|c|}
\hline Building block & Description \\
\hline Customer segments & $\begin{array}{l}\text { Distinct groups of people or organizations a } \\
\text { company aims to reach and serve. }\end{array}$ \\
\hline Value propositions & $\begin{array}{l}\text { Bundle of products and services a company } \\
\text { offers to create value for a specific customer } \\
\text { segment. }\end{array}$ \\
\hline Channels & $\begin{array}{l}\text { The interface of a company with its customers } \\
\text { to, e.g., sell, deliver and communicate a value } \\
\text { proposition. }\end{array}$ \\
\hline Customer relationships & $\begin{array}{l}\text { Types and scope of relationships a company } \\
\text { establishes and maintains with specific } \\
\text { customer segments. }\end{array}$ \\
\hline Revenue streams & $\begin{array}{l}\text { Revenue, a company generates from each } \\
\text { customer segment due to successfully offered } \\
\text { value propositions. }\end{array}$ \\
\hline Key resources & $\begin{array}{l}\text { Required assets to implement the } \\
\text { aforementioned building blocks to realize the } \\
\text { business model. }\end{array}$ \\
\hline Key activities & $\begin{array}{l}\text { Activities a company must perform to deliver } \\
\text { and offer the aforementioned building blocks. }\end{array}$ \\
\hline Key partners & $\begin{array}{l}\text { Network of partners and suppliers providing } \\
\text { resources and performing activities. }\end{array}$ \\
\hline Cost structure & $\begin{array}{l}\text { Total costs incurred to operate a business } \\
\text { model. }\end{array}$ \\
\hline
\end{tabular}

(Osterwalder et al., 2014). In addition, the structure of the Business Model Canvas is divided into the left half, representing aspects of efficiency, and the right half representing aspects of value (Feldmann et al., 2019).

\section{RESULTS}

In the following, the results of conceptualizing business models for remanufactured electric bicycle components using the Business Model Canvas are presented in detail.

\section{Sales Model Classic Sales Model}

To ensure the functionality of electric bicycles is the main value proposition of a circular business model focused on selling additive remanufactured products. For this purpose, used electric bicycle components, e.g., the accumulator or the electric motor, at the end of their useful life are restored to at least the quality level of a new electric bicycle component and returned to the product life cycle (Steinhilper, 1999; British Standards Institution, 2009). In this context, additive remanufacturing enables the recycling of electric bicycle components and causes a positive effect on environmental and social impacts (Colledani and Battaïa, 2016). In addition, production costs can be reduced by preserving the value creation and the diminished use of materials. This leads to cost savings or higher profit margins, which can be passed on to the customer via reduced sales prices (Lange, 2017). The prices for remanufactured products are usually between 


\begin{tabular}{|c|c|c|c|c|}
\hline Key Partners & Key Activities & Value Proposition & $\begin{array}{l}\text { Customer } \\
\text { Relationships }\end{array}$ & $\begin{array}{l}\text { Customer } \\
\text { Segments }\end{array}$ \\
\hline \multirow[t]{3}{*}{$\begin{array}{l}\text { - Workshops } \\
\text { - Logistics provider for } \\
\text { reverse logistics } \\
\text { activities } \\
\text { - Suppliers of new } \\
\text { components } \\
\text { - Third-party service } \\
\text { providers for spare parts } \\
\text { production and delivery, } \\
\text { if applicable }\end{array}$} & $\begin{array}{l}\text { - Remanufacturing } \\
\text { process of the } \\
\text { components } \\
\text { - Analysis of damage } \\
\text { cases } \\
\text { - Upgrades/ additive } \\
\text { retrofitting } \\
\text { - Reverse logistics and } \\
\text { take-back of cores } \\
\text { - Continuous expansion } \\
\text { of marketing and sales } \\
\text { channels } \\
\text { - Customer acquisition } \\
\text { and retention }\end{array}$ & \multirow[t]{3}{*}{$\begin{array}{l}\text { - Ensuring the } \\
\text { functionality of an } \\
\text { electric bicycle } \\
\text { - Cost savings compared } \\
\text { to a new component } \\
\text { - Remanufacturing as an } \\
\text { ecological sales } \\
\text { argument }\end{array}$} & $\begin{array}{l}\text { - Direct contact to } \\
\text { customer } \\
\text { - Take-back systems }\end{array}$ & \multirow[t]{3}{*}{$\begin{array}{l}\text { - B2B (electric bicycle } \\
\text { manufacturers, bike } \\
\text { sharing providers, } \\
\text { workshops, public } \\
\text { clients) } \\
\text { - B2C (private customers) }\end{array}$} \\
\hline & Key Resources & & Channels & \\
\hline & $\begin{array}{l}\text { - Infrastructure, facilities, } \\
\text { and equipment for } \\
\text { production } \\
\text { - Personnel qualification } \\
\text { - Storage space for used } \\
\text { parts } \\
\text { - Used parts }\end{array}$ & & $\begin{array}{l}\text { - Electric bicycle } \\
\text { manufacturers } \\
\text { - Bike sharing providers } \\
\text { - Workshops and } \\
\text { wholesalers } \\
\text { - Offline \& online } \\
\text { marketing } \\
\text { - Reverse logistics }\end{array}$ & \\
\hline \multicolumn{2}{|l|}{ Cost Structure } & Revenue & 目口 & \\
\hline \multicolumn{3}{|c|}{$\begin{array}{l}\text { - Remanufacturing process of the components (production) } \\
\text { - Distribution \& Marketing } \\
\text { - Reverse logistics activities } \\
\text { - Disposal of waste } \\
\text { - Procurement of new spare parts }\end{array}$} & \multicolumn{2}{|c|}{$\begin{array}{l}\text { - Sales revenue from remanufactured components } \\
\text { - Increase in brand value } \\
\text { - Increased market share through new offerings } \\
\text { - Reduction of disposal costs }\end{array}$} \\
\hline
\end{tabular}

FIGURE 3 | Business model canvas of a sales business model for electric bicycles through additive remanufacturing.

40 and $80 \%$ below those of equivalent new products (Lange, 2017). Remanufacturing can also secure the supply of spare parts in the long term (Dombrowski et al., 2020). Especially due to the Corona pandemic and the growing demand of electric bicycles in combination, exacerbate the shortage of spare parts for bicycles (Wrede, 2021). By remanufacturing components from products currently on the market, it is possible to cover a portion of the spare parts demand even after the end of the series production phase. Missing spare parts can be manufactured using additive manufacturing (Montero et al., 2020). Thus, supply chain bottlenecks or interruptions can be intercepted leading to an increased supply chain resilience in the short term by additive remanufacturing (Li et al., 2017; Bag et al., 2019). Finally, additive remanufacturing leads to an increase in the availability of electric bicycle components for the customer.

To establish additive remanufacturing as a sales business model, the key activities, according to Porter (2014), production, internal and external logistics, marketing \& sales, must be addressed. Therefore, in terms of production, remanufacturing processes to disassemble used electric bicycles, restore and replace components, and test individual parts must be introduced. Furthermore, adequate take-back channels or systems need to be established for economic additive remanufacturing (Lewandowski, 2016). Procurement must ensure a continuous supply of constant quantities of used electric bicycle components over time, preferably of consistent quality and at reasonable prices (Guide and Wassenhove, 2009). In addition, marketing and sales channels need to be expanded to retain existing customers and acquire new ones. In addition to the existing partnerships from the current business model, key partners for additive remanufacturing are, in particular, workshops, partners for core collection, and suppliers of spare parts. For an economically feasible remanufacturing, framework contracts for exchanging information and data with the OEM can be concluded. The existing infrastructure and production site, including machinery, equipment, inventory, and qualified employees, are considered key resources for introducing the business model. In addition, cores are required as raw materials for remanufacturing. Furthermore, spare parts must be reserved or produced by additive manufacturing. However, this requires the spare parts first to be tested for their technical feasibility for additive manufacturing (Collan and Michelsen, 2020).

The customer relationship in remanufacturing is essential. On the one hand, the customer is mainly responsible for the return and quality of the core. On the other hand, offering an environmentally friendly alternative by saving energy and 
resources in remanufactured products can increase customer satisfaction and achieve longer customer retention (Dias et al., 2013; Liu et al., 2016). Direct personal contact with, e.g., workshops and the customer is a prerequisite. By introducing additive remanufacturing, new customer segments are addressed. Thus, brand building or market expansion can be created for environmentally and economically conscious customer groups. The sales model offers potential for new business relationships in business-to-business (B2B) and business-toconsumer (B2C). The customer groups in B2B are, e.g., electric bicycle manufacturers, bike-sharing providers, workshops, or public clients. In $\mathrm{B} 2 \mathrm{C}$, the focus is primarily on customers who value environmentally friendly products and economic advantages (Guide and Li, 2010).

For this business model, new sales channels, e.g., electric bicycle manufacturers or bike-sharing providers or already existing sales channels like direct sales through, e.g., wholesalers or workshops to distribute remanufactured electric bicycle components, can be used. Regarding the return of used electric bicycle components for remanufacturing, companies can take them back or repurchase them from their customers or dealers. The company is therefore dependent on the customer or dealer taking back the electric bicycle components. In general, there are already established incentive systems to motivate users to return used products. According to Östlin et al. (2008), there are various ways or systems of taking back used products, such as ownership-based take-back, take-back through purchasing used parts, or deposit systems. In the case of electric bicycles, the return is usually performed by private customers due to defects in components within the warranty claim. According to Häfner et al. (2021), the most common reasons for a workshop visit are defects of the motor or the accumulator.

As part of the business model, costs are incurred with the remanufacturing process, including charges for the procurement of spare parts, employees, the reverse supply chain, and storage costs. Charges for disposal waste of defective electric bicycle components must also be considered. This is especially the case for electric bicycle accumulators, as these components are classified as "industrial batteries." Therefore, the European Directive 2006/66/EC provides the legal framework for the marketing, return, and environmentally friendly disposal of accumulators (Häfner et al., 2021). In addition, costs are incurred for sales and marketing activities. Additive remanufacturing can generate revenues through the sale of remanufactured electric bicycle components and spare parts. At the same time, disposal costs can be saved, especially through the remanufacturing of accumulators. Also, offering remanufactured electric bicycle components can increase market share and enhance market value. Figure 3 summarizes the Business Model Canvas of the sales business model.

However, there are currently several barriers to adopting additive remanufacturing for electric bicycles, such as a high degree of innovation, short product life cycles, and a currently low return of cores (Häfner et al., 2021). The lack of standardization of typical electric bicycle components, such as accumulators, motors, sensors, and controllers, complicates remanufacturing as, e.g., individual fixtures and tools must be used for different motor generations. Also, a lack of compatibility between components from different manufacturers and between different models from individual manufacturers leads to increased complexity.

For bicycle retailers, remanufacturing of mechatronic or electronic components such as the motor, accumulator, or display is not common. As a result, these components are sent to the OEM instead of being repaired or remanufactured, resulting in a complete replacement with new components (Häfner et al., 2021). In addition, the limited access to data needed for repair or remanufacturing purposes makes it difficult for companies to adopt remanufacturing. Also, high labor costs can be a barrier for companies to implement remanufacturing, as these activities are mainly manual tasks (Lange, 2017). Legal regulations regarding the reusability of (safety-relevant) electric bicycle components and intellectual property must also be considered when adopting remanufacturing (Hartwell and Marco, 2016). If remanufacturing takes place in-house, it requires a comprehensive system to return used electric bicycle components. For this purpose, companies need logistical systems to take back electric bicycle components and transfer them to the most suitable value-added cycle (Bungard, 2018).

Remanufactured products can displace competing products of the same company and "cannibalize" the main market and possibly reduce the higher profit margin from the sale of new components (Atasu et al., 2008; Guide and Li, 2010). In this context, cannibalization refers to the competitive marketing of products that address the same or similar needs at different prices by the same company (Winter, 2009). Therefore, to avoid cannibalization of the market of new products, remanufactured products are usually sold to other customer groups in other markets, or sales are delayed to coincide with the sale of new products (Walther, 2010).

\section{Mass Customization and Open-Source Model}

As with the remanufacturing sales business model of electric bicycle components, the main value proposition is to ensure the functionality of the electric bicycle. This business model additionally considers the individual customer needs of electric bicycle component features within a defined framework (Gassmann and Frankenberger, 2016; Koller et al., 2020). Customers can choose their own ideas for designing components, color, design, or engraving, etc. The specifications and design proposals are made available using open-source software. In the business model, by involving customers, innovative ideas are generated and problems are effectively solved (Gassmann and Frankenberger, 2016). To introduce remanufacturing in combination with mass customization and open-source as a business model, the key activities, according to Porter (2014), production, internal and external logistics, marketing \& sales, and customer service, must be addressed. The company can build on its existing structures for the sale of individualized electric bicycle components. In addition, new organizational structures must be created for services, such as evaluating and analyzing the ideas and providing a platform for the community to exchange ideas. 


\begin{tabular}{|c|c|c|c|c|}
\hline Key Partners & Key Activities & Value Proposition & $\begin{array}{l}\text { Customer } \\
\text { Relationships }\end{array}$ & $\begin{array}{l}\text { Customer } \\
\text { Segments }\end{array}$ \\
\hline \multirow[t]{3}{*}{$\begin{array}{l}\text { - Workshops } \\
\text { = Logistics provider for } \\
\text { reverse logistics } \\
\text { activities } \\
\text { = Suppliers of new } \\
\text { components } \\
\text { " Third-party service } \\
\text { providers for spare parts } \\
\text { production and delivery, } \\
\text { if applicable } \\
\text { - User }\end{array}$} & $\begin{array}{l}\text { " Remanufacturing } \\
\text { process of the } \\
\text { components } \\
\text { " Analysis of damage } \\
\text { cases } \\
\text { " Upgrades/ additive } \\
\text { retrofitting } \\
\text { " Reverse logistics and } \\
\text { take-back of cores } \\
\text { = Continuous expansion } \\
\text { of marketing and sales } \\
\text { channels } \\
\text { " Customer acquisition } \\
\text { and retention } \\
\text { - Platform for the } \\
\text { exchange of ideas } \\
\text { - Analysis and evaluation } \\
\text { of ideas } \\
\text { - Ideas contest }\end{array}$ & \multirow[t]{3}{*}{$\begin{array}{l}\text { " Ensuring the } \\
\text { functionality of an } \\
\text { electric bicycle } \\
\text { " Cost savings compare } \\
\text { to a new component } \\
\text { - Remanufacturing as ar } \\
\text { ecological sales } \\
\text { argument } \\
\text { - Individualization of } \\
\text { remanufactured } \\
\text { components }\end{array}$} & $\begin{array}{l}\text { - Direct contact to } \\
\text { customer } \\
\text { - Take-back systems } \\
\text { - Customer is also source } \\
\text { of ideas for new } \\
\text { innovations }\end{array}$ & \multirow[t]{3}{*}{ - B2C (private customers) } \\
\hline & Key Resources & & Channels & \\
\hline & $\begin{array}{l}\text { - Infrastructure, facilities, } \\
\text { and equipment for } \\
\text { production } \\
\text { - Personnel qualification } \\
\text { - Storage space for used } \\
\text { parts } \\
\text { - Used parts }\end{array}$ & & $\begin{array}{l}\text { " Electric bicycle } \\
\text { manufacturers } \\
\text { " Bike sharing providers } \\
\text { - Workshops and } \\
\text { wholesalers } \\
\text { - Offline \& online } \\
\text { marketing } \\
\text { " Reverse logistics } \\
\text { - Digital platform for } \\
\text { information exchange }\end{array}$ & \\
\hline \multicolumn{2}{|l|}{ Cost Structure } & Revenue & 目员 & \\
\hline \multicolumn{3}{|c|}{$\begin{array}{l}\text { = Remanufacturing process of the components (production) } \\
\text { = Distribution \& Marketing } \\
\text { = Reverse logistics activities } \\
\text { = Disposal of waste } \\
\text { " Procurement of new spare parts } \\
\text { - Incentivising new design ideas } \\
\text { - Events } \\
\text { - Development costs for the platform } \\
\text { - Costs for operating the platform }\end{array}$} & \multicolumn{2}{|c|}{$\begin{array}{l}\text { - Sales revenue from remanufactured components } \\
\text { - Increase in brand value } \\
\text { - Increased market share through new offerings } \\
\text { " Reduction of disposal costs } \\
\text { - Sale of spare parts / CAD data } \\
\text { - Reduction of innovation costs and market research }\end{array}$} \\
\hline
\end{tabular}

FIGURE 4 | Business model canvas of a mass customization and open-source business model for electric bicycles through additive remanufacturing (Aspects already mentioned in the sales model are shown in gray, specific aspects of the mass customization and open-source business model are highlighted in black).

In addition to the key partners described in the remanufacturing sales business model, the business model directly depends on its customers and their motivation to be part of the community. The motives for the customer to participate in such a business model can be extrinsic and intrinsic. For example, the company can offer a monetary reward to its customers due to their support. Intrinsic motivation of the customer could arise from loyalty to the company or the attraction of the task as such (Gassmann and Frankenberger, 2016). In addition to the requirements for the production and processing of spare parts, design ideas, as well as technical data and data on the product life cycle, are key resources in this business model. By collecting product usage data over multiple usage cycles, conclusions can be drawn to improve the design and functionality of the electric bicycle components (Nasr and Thurston, 2006). Core acquisition and collection are also of particular importance. The company typically also benefits from an intensified customer relationship, as customizing a product requires greater collaboration, and the company receives direct feedback from the customer. As a result, the customer becomes more emotionally attached to the product and the company (Gassmann and Frankenberger, 2016). Therefore, many companies can better respond to customers' needs by customizing products and services to a greater extent (Bovensiepen et al., 2016). Customers are also networked via a platform and can thus easily get in touch with each other and the company.

Introducing individualized products through additive remanufacturing expands the market by further customer 
segments. The company can thereby differentiate itself from the competition and thus create a brand-building or market expansion. The company addresses niche markets for environmentally conscious customer groups and customers who value individualized products (Koller et al., 2020). With the help of additive manufacturing, it is possible to individualize electric bicycle components from mass production and implement them at scalable and reasonable prices. Also, the manual steps of remanufacturing offer the possibility to produce customized electric bicycle components (Koller et al., 2020). Here, two advantages of additive manufacturing can be combined: on the one hand, the elimination of product-dependent set-up times and production preparations, which enables the cost-effective production of individual pieces, and on the other hand, the independence of additive manufacturing from the complexity of the component (Arndt et al., 2018). In addition to the channels described for the sales business model with additive remanufacturing, contact with the customer via user-friendly online platforms is a prerequisite. The platform is an essential part of the business model, as it enables communication and information exchange between companies and customers as well as between customers. New ideas and announcements are shared with the community via the platform. In this business model, additional costs are incurred through the development and operation of the online platform. The company also needs to encourage its community by organizing events, contests, motivating them to participate in certain activities, etc. These activities are essential for the community's involvement and promote enthusiasm for participation in the business model. Rewards for good ideas from the community are also possible.

In addition to the revenues from the sale of individualized products, development costs and market research can be reduced. The community provides ideas for new designs of electric bicycle components. The company can thus learn more about the preferences of customers for future electric bicycle components and spare parts. Furthermore, data on the product life cycle can be sold to interested parties. Individualization not only leads to more intensive customer loyalty but also an increase in customer satisfaction. With higher customer loyalty and satisfaction, the chances increase that customers will continue to buy products, which ultimately increases revenue (Bloching et al., 2015; DIHK, 2017). Figure 4 shows the Business Model Canvas of mass customization and open-source business model of electric bicycle components through additive remanufacturing. Aspects already mentioned in the sales model are shown in gray. Specific aspects of the mass customization and open-source business model are highlighted in black.

Customization through additive remanufacturing enables companies to tailor their electric bicycle components and services more precisely to individual customer requirements and offer value-added solutions that complement existing products with additional benefits. The required digital transformation of a company for this business model affects its strategy, organization, project management, and culture in equal measure (Commerzbank, 2017). In this transformation, companies face not only technical challenges but also social and organizational ones. Challenges in introducing this business model are initiating change measures in the organization, personnel, and corporate culture (Rürup and Jung, 2021). For the business model to be successful, a community must be willing to develop new ideas for the company. Customization options for the electric bicycle components must be precisely formulated and communicated to design proposals and solutions to problems that the community can develop. In addition, it is essential for this business model that there is a market with an interested community. In this context, the company must strive to recruit users in the long term since they are mainly responsible for the product development process. In addition, products and processes must be analyzed with regard to design and modification through mass customization. The adaptability of electric bicycle components to customer needs must be given (Gassmann and Frankenberger, 2016). In this context, the definition of the customer decoupling point-the point at which an order changes from an anonymous stock production to a customer-specific order-is important for this business model, as otherwise the diversity of variants and thus the complexity in production could increase significantly (Koller et al., 2020).

\section{Service Models Leasing Model}

Bicycle leasing is a use-oriented and service-dominant business model, as it fulfills consumers' needs for bicycles through intangible leasing services without owning them (Huang et al., 2021). The service provider (which may not necessarily be a bicycle producer) owns the bicycle but offers customers longterm exclusive access to using the bicycle in return for the payment of an agreed leasing fee (Williams, 2007). This is an owner-substitute use strategy (Scholl et al., 2013). The costs for maintenance, insurance, repair, remanufacturing, and disposal are the lessor's responsibility. However, the lessor can also gain data on the use, maintenance, and repair of the bicycles through status monitoring (Häfner et al., 2021). Since the lessor remains in possession of the electric bicycles, the electric bicycles are returned to the lessor at the end of the contract period or in the event of a defect. This simplifies the take-back system of used electric bikes compared to classic sales models, where the return is dependent on the customer. In order to finally restore the functionality of the electric bicycles, the lessor has the option of replacing the defective components through remanufacturing, ensuring new part quality. By supporting the circulation of components, the lessor can strengthen more sustainable and resource-efficient handling of electric bicycle components. After the contract is fulfilled, the lessee has the option to purchase the electric bicycle and thus become the owner (de Brito and Peters, 2010; Huang et al., 2021).

As a business model, leasing offers both lessors and customers several value propositions compared to purchasing an electric bicycle. The industrial remanufacturing of used components strengthens a more sustainable and resource-efficient use of electric bicycle components. It also prepares manufacturers for a possible expansion of regulation for extended producer responsibility of motors and batteries (Williams, 2007; Steeneck and Sarin, 2018). Improved circularity also satisfies customers' need for sustainable products and transfers any potential loss 


\begin{tabular}{|c|c|c|c|c|c|}
\hline Key Partners & Key Activities & \multicolumn{2}{|c|}{ Value Proposition } & $\begin{array}{l}\text { Customer } \\
\text { Relationships }\end{array}$ & $\begin{array}{l}\text { Customer } \\
\text { Segments }\end{array}$ \\
\hline \multirow[t]{3}{*}{$\begin{array}{l}\text { - Manufacturers of electric } \\
\text { bicycles (if they do not } \\
\text { offer the leasing } \\
\text { themselves) } \\
\text { - Workshops, which } \\
\text { ensure repair and } \\
\text { remanufacturing } \\
\text { - Stationary or online } \\
\text { bicycle dealer } \\
\text { - Suppliers of new or } \\
\text { reconditioned } \\
\text { components }\end{array}$} & $\begin{array}{l}\text { - Leasing of electric } \\
\text { bicycles } \\
\text { - Customer support } \\
\text { - Establishment and } \\
\text { maintenance of strategic } \\
\text { partnerships } \\
\text { - Repair, remanufacturing } \\
\text { and disposal of electric } \\
\text { bicycles }\end{array}$ & \multirow{3}{*}{\multicolumn{2}{|c|}{$\begin{array}{l}\text { - Use-oriented and } \\
\text { service-dominant } \\
\text { business model } \\
\text { - Leasing, that includes } \\
\text { maintenance, insurance, } \\
\text { repair, remanufacturing } \\
\text { and disposal }\end{array}$}} & $\begin{array}{l}\text { - Improve information } \\
\text { exchange, customer } \\
\text { loyalty, and (product) } \\
\text { quality } \\
\text { - If the leasing is provided } \\
\text { with an additional } \\
\text { service offer, the contact } \\
\text { to the customer through } \\
\text { maintenance and repair } \\
\text { is particularly close }\end{array}$ & \multirow[t]{3}{*}{$\begin{array}{l}\text { - Private customers } \\
\text { - Employers who offer } \\
\text { leasing for their } \\
\text { employees }\end{array}$} \\
\hline & Key Resources & & & Channels & \\
\hline & $\begin{array}{l}\text { - Administration (IT, } \\
\text { customer support, } \\
\text { marketing, strategy) } \\
\text { - For remanufacturing: } \\
\text { Technologies (e.g. } \\
\text { automated assembly/ } \\
\text { disassembly processes), } \\
\text { Informative and } \\
\text { knowledge, Logistics } \\
\text { infrastructure for core } \\
\text { return }\end{array}$ & & & $\begin{array}{l}\text { - Stationary or online } \\
\text { dealers who offer } \\
\text { leasing. } \\
\text { - Special providers for } \\
\text { company bicycle leasing } \\
\text { or for leasing with all- } \\
\text { round service of electric } \\
\text { bicycles are often } \\
\text { available online }\end{array}$ & \\
\hline Cost Structure & & & \multicolumn{2}{|c|}{ Revenue Stream } & \\
\hline \multicolumn{3}{|c|}{$\begin{array}{l}\text { - Production costs for the electric bicycles } \\
\text { - Running Costs: maintenance, repair, remanufacturing, disposal, costs } \\
\text { for office buildings, transport costs, personnel costs for the leasing } \\
\text { contracts and customer support }\end{array}$} & \multicolumn{3}{|c|}{$\begin{array}{l}\text { - Monthly or annual payments by the customers } \\
\text { - For the customer, leasing makes it possible to obtain a high-priced } \\
\text { electric bicycle with the latest technology at a lower acquisition cost } \\
\text { - Lessor can also gain data on the use, maintenance and repair of the } \\
\text { bicycles through status monitoring }\end{array}$} \\
\hline
\end{tabular}

FIGURE 5 | Business model canvas of a leasing business model for electric bicycles through remanufacturing.

of market value to the lessor (Huang et al., 2021). In the case of company bicycle leasing, there is also the added benefit that provides the employer with a positive image and increases the attractiveness of the workplace. Furthermore, company bicycles offer tax advantages to the employer. The employer saves on non-wage labor costs, as the leasing payments can be recognized as operating expenses. For the employee, the salary conversion reduces the taxable income (Merten, 2017). The lessor, which may be an agent or an OEM, typically offers lessees a fullservice lease that includes a maintenance package and also spare parts services. Consequently, the structure of a lease (consisting of the length of the lease period, the specified maintenance services and the services required by the lessee, the price of the lease, etc.) and the maintenance strategies characterize the lessor's key activities (Husniah et al., 2021). In addition to the leasing of electric bicycles, the key activities of this business model also include customer support, the establishment, care of strategic partnerships, and the repair, remanufacturing, and disposal of electric bicycles. In the case of leasing subscriptions with additional all-round service, tire changes are carried out, or defective parts are repaired directly, depending on the provider and the scope of the subscription (Scholl et al., 2013; Ma et al., 2020).
Key partners for a bicycle lessor are the manufacturers of electric bicycles (if they do not offer the leasing themselves), the stationary or online bicycle dealer for closing the leasing contracts, as well as the return of the bicycles at the end of the leasing contract. Also, workshops, which ensure the remanufacturing and repair, as well as suppliers of new or also reconditioned components, are important partners. Customer relationship, in particular, plays a central role for leasing providers. The leasing contract creates a relationship between the lessor and the lessee. This can improve information exchange, customer loyalty, and (product) quality (Goedkoop et al., 1999). If the leasing even provides an additional service offer, the contact to the customer through maintenance and repair is particularly close. The customer segment for electric bicycle leasing is divided into two main areas: Private customers and employers who offer leasing for their employees (Merten, 2017). The sales channels run through stationary or online dealers who offer to lease. Special providers for leasing company bicycles or for leasing with all-around service of electric bicycles can often be found online.

In order to link electrical bicycle leasing with remanufacturing, a business infrastructure is needed that is able to manage the remanufacturing operations and the logistics network for the take-back and delivery activities. Key 
resources include the know-how of the employees to implement the remanufacturing process, the necessary technology and infrastructure for the remanufacturing process as described in the sales model. When introducing and implementing the business model of leasing with remanufacturing, various costs must be taken into account. In addition to the running costs for personnel and facilities, the machine acquisition costs for the remanufacturing process must also be considered. Furthermore, costs for the procurement of spare parts and the disposal of components that can no longer be repaired are required. Transport and logistics of the remanufacturing system must also be taken into account.

Leasing represents a modified revenue model compared to the classic sales model. Instead of a one-off payment, monthly payments are made by the lessee to the lessor. This reduces the financial pressure on the lessee and provides the lessor with a stable flow of liquidity (Huang et al., 2021). For the customer, leasing makes it possible to obtain a high-priced electric bicycle with the latest technology at a lower acquisition cost, which reduces the barriers to purchase (Häfner et al., 2021). Customers pay an annual or monthly leasing fee with a refundable deposit, regardless of usage (e.g., driving distance or duration) (Huang et al., 2021). Figure 5 shows the Business Model Canvas of the leasing business model.

One problem with the introduction of leasing as a new business model is determining the residual value of electric bicycles. The residual values of electric bicycles are still challenging to determine due to a lack of leasing experience in the bicycle market, which means that leasing rates are often relatively high (Häfner et al., 2021). In addition, the OEM that leases new products and takes back used products that are then remanufactured and sold faces the problem of determining an end-of-life strategy for a leased product (Steeneck and Sarin, 2018).

Leasing also requires a high level of service, especially for the full-service package, which must be guaranteed in order to meet customer satisfaction. In addition to these challenges, which relate to implementing the business model in the company, a change is also required among customers' mindsets. An electric bicycle does not necessarily have to be owned, but the product can also be leased.

\section{Bike-Sharing as a Product-Service System}

Bike-sharing, which is considered in this article in combination with the remanufacturing of electric bicycles, is a resultoriented product-service system that integrates a network of cooperation with organizational, logistic, and technological innovations (Tukker, 2004; Moro et al., 2018). In the case of bike-sharing, users are charged based on usage, such as how long they ride or how far they ride their electric bicycle. The electric bicycle itself remains the property of the bikesharing service provider who is responsible for maintenance, insurance, and repair costs (Williams, 2007). In B2C bikesharing business models, electric bicycles are made available to customers via free-floating or docking stations, while digital platforms are used to conduct payment, check availability, etc. (Sun, 2021). To be competitive, customers must be given access to always-functional electric bicycles that are available at central locations in the city. Advanced functionalities with leading performance can be an additional factor to convince customers of the product. To provide such an offer, the provider should implement a number of value-added services, such as periodic take-back and upgrade of the bicycles. By performing regular updates through remanufacturing, the producer could ensure the continuous monitoring and recovery of the products. The producer also has the possibility to include technological or aesthetic improvements as well as new functions, which keeps customer satisfaction high and extends both the physical life and the value of the products (Chierici and Copani, 2016).

The key activities of bike-sharing are renting electric bicycles to customers and creating high customer satisfaction through an up-to-date, functional, and charged fleet of electric bicycles reasonably distributed throughout the urban area. The provider must ensure the quality of the products and services offered while maintaining the affordable cost and robustness of the electric bicycles (Moro et al., 2018). The combination with remanufacturing is usually carried out in cooperation with a further service provider. By remaining in the ownership of the sharing provider and the need for regular maintenance, servicing, and repair during use, incentives are created for service providers to improve the durability of the individual components. In addition, the provider must also take care of the disposal or recycling of electric bicycle components that can no longer be recovered.

Bike-sharing is carried out by private or municipal providers who cooperate with various partners. The key partners in this business model are the manufacturers of the electric bicycles as well as service providers who carry out the maintenance, repair, and remanufacturing of the electric bicycles. In addition, the providers of sharing systems often work together with public transport or the city administration to set up bicycle fleets at bus stops or central urban locations. To complement classic bike-sharing with remanufacturing, cooperation with service providers for maintenance and repair is being considered and companies that undertake the remanufacturing of electric bicycles.

The bike-sharing business model has an intensive customer relationship. The most important factor in the success of a bikesharing system is its ability to meet users' varying demands. Due to the demand-oriented access, random fluctuations in daily demand patterns of usage must be identified and estimated, and the system must be planned and managed to maximize customer satisfaction. The everyday users have to be confident that they can rely on the availability and operability of electric bicycles (Alvarez-Valdes et al., 2016). The customer has no uncertainties about maintenance and repair, as the product does not become his property (Huang et al., 2021). However, the direct contact with the customers is rather low, as these services are not performed for individual customers but as maintenance work on the entire electric bicycle fleet. To increase customer loyalty and the appreciation of the product, some bike-sharing providers offer additional services for their customers, such as renting safety equipment, extra use time for long-term members, or special electric bicycles (Moro et al., 2018). 
So far, no clear statement can be made about the customer segments. Fishman's (2016) literature review on bike-sharing shows that the users of bike-sharing systems without electric bicycles tend to be male, have an average income, and have a higher education. On the other hand, according to an American study, customers who use classic bike-sharing services without electric bicycles are more often younger and female, less likely to own a bicycle or car, and have a lower income (Buck et al., 2013). Huang et al. (2021) have studied the customers of electric bicycle sharing systems and describe that this system is particularly attractive for lower-income consumers who do not want to commit to the financial obligation of a leasing contract. By using electrical bike-sharing, users are introduced to electric bicycle usage and may switch to leasing later.

In addition to a bicycle fleet, bike-sharing providers also need a mobile operating system to manage the utilization of the fleet and communicate with customers as key resource. To introduce bike-sharing business models with remanufacturing, necessary technology and infrastructure is needed as described in the sales models. The continuous collection of information on product usage and conditions, component failure and obsolescence rates, user behavior is necessary to optimize reverse logistics and remanufacturing processes.

For this business model, sales channels are mainly customers who use the offer of bike-sharing services. Also, the offline visibility of the electric bicycles and docking stations in front of transport stops, city centers, and central places is particularly important to make customers aware of the sharing offer. Revenue streams are generated through payment by customers per usage (e.g., driving distance or duration).

The financial costs for acquiring an electrical bicycle fleet to start a bicycle sharing system are high since it is necessary to cover the negative cash flow in the first months (Moro et al., 2018). Also, providers may have doubts about the price level, as they want to be competitive (Fishman, 2016). Due to the high initial implementation costs, bike-sharing providers need to consider alternative ways to raise revenue to keep the business model running continuously (e.g., sponsorship), effectively plan their operations and maintenance costs, and develop a robust demand estimate (Moro et al., 2018). According to Chierici

\begin{tabular}{|c|c|c|c|c|c|}
\hline Key Partners & Key Activities & \multicolumn{2}{|c|}{ Value Proposition } & $\begin{array}{l}\text { Customer } \\
\text { Relationships }\end{array}$ & $\begin{array}{l}\text { Customer } \\
\text { Segments }\end{array}$ \\
\hline \multirow{3}{*}{$\begin{array}{l}\text { - Manufacturers of electric } \\
\text { bicycles } \\
\text { - Workshops, which } \\
\text { ensure repair and } \\
\text { remanufacturing } \\
\text { - Service providers who } \\
\text { carry out the } \\
\text { maintenance and repair } \\
\text { - Service providers for } \\
\text { remanufacturing } \\
\text { - Public transport, city } \\
\text { administration }\end{array}$} & $\begin{array}{l}\text { - Rental of fully functional } \\
\text { and charged electric } \\
\text { bicycles } \\
\text { - Establishment of } \\
\text { strategic partnerships } \\
\text { " Repair, remanufacturing } \\
\text { and disposal of electric } \\
\text { bicycles }\end{array}$ & \multirow{3}{*}{\multicolumn{2}{|c|}{$\begin{array}{l}\text { - Flexible, demand- } \\
\text { oriented use } \\
\text { - Regular maintenance, } \\
\text { repair of damage and } \\
\text { remanufacturing of } \\
\text { components } \\
\text { - Product periodic take } \\
\text { back and upgrade }\end{array}$}} & $\begin{array}{l}\text { - Provision of various } \\
\text { services (maintenance, } \\
\text { repair, charging) } \\
\text { - Rental of bicycles } \\
\text { - If applicable, additional } \\
\text { services such as safety } \\
\text { equipment }\end{array}$ & \multirow[t]{3}{*}{$\begin{array}{l}\text { - Particularly attractive for } \\
\text { lower-income } \\
\text { consumers who do not } \\
\text { want to commit the } \\
\text { financial obligation of a } \\
\text { leasing contract }\end{array}$} \\
\hline & - Key Resources & & & - Channels & \\
\hline & $\begin{array}{l}\text { " Administration (IT, } \\
\text { customer support, } \\
\text { marketing, strategy) } \\
\text { " For remanufacturing: } \\
\text { Technologies (e.g. } \\
\text { automated assembly/ } \\
\text { disassembly processes), } \\
\text { Informative and } \\
\text { knowledge, Logistics } \\
\text { infrastructure for core } \\
\text { return } \\
\text { - Electric bicycle fleet } \\
\text { - Technical infrastructure } \\
\text { (app, website) }\end{array}$ & & & $\begin{array}{l}\text { - Sharing App } \\
\text { - Offline visibility of the } \\
\text { electric bicycles to make } \\
\text { customers aware of the } \\
\text { sharing offer }\end{array}$ & \\
\hline Cost Structure & & & \multicolumn{2}{|c|}{ Revenue Stream } & \\
\hline \multicolumn{3}{|c|}{$\begin{array}{l}\text { - High Acquisition costs for the bicycle fleet } \\
\text { " Running Costs: maintenance, repair, remanufacturing, disposal, } \\
\text { personnel costs, costs for office buildings and transport costs. }\end{array}$} & \multicolumn{3}{|c|}{ - Payment by customers per use (per minute/ kilometer) } \\
\hline
\end{tabular}

FIGURE 6 | Business model canvas of a product-service-system business model, bike-sharing of electric bicycles in combination with remanufacturing (Aspects already mentioned in the service model are shown in gray, specific aspects of the product-service system are highlighted in black). 
and Copani (2016), investment needs, capital availability, and operating costs are the main factors considered as barriers to the economic viability of product-service-system business models. Figure 6 summarizes the Business Model Canvas of the productservice system.

The development of this business model is associated with several potential obstacles. For example, it must be ensured that the bicycles are distributed throughout the city (free-floating) or that the availability of electric bicycles is well-balanced at the docking stations. In addition, the operability of electric bicycles must also be ensured. The customer satisfaction of the bikesharing service also depends on the user-friendliness of the app. Possible annoyances for customers can be poor geolocation, poor charging status updates, or a poor reservation process (Nasr et al., 2019). In addition, rental bicycles are used more intensively and handled with less care than private bicycles, which should be considered when purchasing or designing electric bicycles (ADFC, 2020). Overall, the success of a product-service-system solution also depends heavily on customer attitudes to this business model, like described in the leasing business model.

\section{DISCUSSION}

Due to the speed of innovation and the lack of standards for specific components of an electric bicycle (e.g., motor, accumulator, controller), the implementation of circular business models with additive remanufacturing is currently challenging. At the same time, according to Häfner et al. (2021), users of electric bicycles welcome sustainable business models in the form of remanufactured components and the reparability and extension of the useful life of electric bicycles.

In order to support companies in the electric bicycle industry in the transformation of currently linear product life cycles of electric bicycle components into closed product cycles, possible sustainable business models were identified and analyzed. Based on these findings, two sales and two service business models were defined that are particularly suitable for remanufacturing electric bicycles combined with additive manufacturing. In the four circular business models described above, the focus is no longer just on selling electric bicycles but on an electric bicycle's entire life cycle, which must be considered. In a circular business model, value is generated along the entire value chain. In this context, remanufacturing represents a promising solution approach for a sustainable electric bicycle industry. Through remanufacturing, product cycles are closed, and the reuse of used products at the end of their useful life is made possible while maintaining or restoring the product design and the associated product properties (Verein Deutscher Ingenieure, 2002; Westkämper and Warnecke, 2010). Thereby also resulting in a closer relationship with the end customer, as the latter plays an elementary role in the value cycle. Due to the strong increase in the number of electric bicycles sold in recent years and the time delay with which corresponding defects occur, a numerical growth in defective components can be expected in the future. The most promising electric bicycle components for remanufacturing are the motor and the accumulator because of their importance for the utility, the defects that occur on them, and the high value of the components.

It is also apparent that with circular business models, the individual partners within the value chain must collaborate more closely. In the electric bicycle industry, a single company will probably not be able to close a product cycle. Furthermore, information on, e.g., repair options, hazardous materials, or core availability, must be exchanged between the companies to enable economically feasible remanufacturing. The business models described with the Business Model Canvas serve as a basis for introducing circular business models in the electric bicycle industry. However, a detailed and structured concept based on company-specific requirements is still necessary to enable a simple introduction of a circular business model. To test the success for such a business model, the practical feasibility in technical and organizational operation must be evaluated.

To determine the benefits of circular business models, further research activities are planned in the AddRE-Mo project. The potential future contribution of circular business models in the electric bicycle industry is investigated from an environmental, economic, and social perspective by developing simulation models. Thereby, the determination of reducing greenhouse gas emissions by introducing circular business models by means of additive remanufacturing of electric bicycles is of particular interest.

\section{CONCLUSION}

In this paper, we approach the emerging circular business model concepts for additive remanufacturing of electric bicycles from a business model perspective, analyzing the extent to which additive remanufacturing can be considered a solution for the circularity of electric bicycles. Based on market and literature research and three surveys with users, electric bicycle workshops and experts in the electric bicycle sector, four circular business models combining remanufacturing in combination with additive manufacturing were described: (1) classic sales model, (2) mass customization and open-source model, (3) leasing model, and (4) bike-sharing as a product-service system.

This article contributes to the circular business model literature by showing the potential of different circular business models combining remanufacturing with additive manufacturing. The description of these business models will help managers design viable business models in the context of sustainable electric bicycles. The general guidance for the introduction of circular business models in the field of electric bicycles regarding different aspects, e.g., key partners, key activities, value proposition, was highlighted. To the best of our knowledge, this is the first work that deals with different possible business models in the field of additive remanufacturing of electric bicycles.

However, limitations regarding the collected data from the surveys with users, electric bicycle workshops, and experts in the electric bicycle sector from research and industry could bias the aforementioned results due to the sample size, selection of participants, and timeframe regarding the feasibility of additive 
remanufacturing in the electric bicycle industry. The validity could be increased by further surveys and the inclusion of other participant groups, such as bike-sharing providers and their users. Further research is needed to develop concepts of the different business models and examine their practical feasibility in technical and organizational operations. Also, the extent to which electric bicycles can be economically remanufactured at the component level must be analyzed. In addition, market acceptance and the procurement of the cores must be examined.

\section{DATA AVAILABILITY STATEMENT}

Publicly available datasets were analyzed in this study. This data can be found here: https://www.ipa.fraunhofer. de/de/Publikationen/studien/zukunftstrend_nachhaltige_ elektrofahrraeder.html.

\section{REFERENCES}

ADFC. (2020). Bike-Sharing. Available online at: https://www.adfc.de/artikel/bikesharing (accessed November 15, 2021).

Alvarez-Valdes, R., Belenguer, J. M., Benavent, E., Bermudez, J. D., Muñoz, F., Vercher, E., et al. (2016). Optimizing the level of service quality of a bikesharing system. Omega 62, 163-175. doi: 10.1016/j.omega.2015.09.007

Amrhein, S. (2017). Wertstoffkreisläufe im Kontext neuer Mobilitätskonzepte [Universität Augsburg]. Available online at: https://opus.bibliothek.uniaugsburg.de/opus4/frontdoor/deliver/index/docId/4072/file/Dissertation_ Amrhein_Sebastian.pdf (accessed November 15, 2021).

Arndt, A., Anderl, R., Kegelmann, K., and Kleiner, S. (Hrsg.) (2018). "Automatisierung in der kundenindividuellen Additiven Serienfertigung," in Additive Serienfertigung: Erfolgsfaktoren und Handlungsfelder für die Anwendung, eds R. Lachmayer, R. B. Lippert, and S. Kaierle (Berlin: Springer Vieweg), 1-16. doi: 10.1007/978-3-662-56463-9_1

Atasu, A., Guide, V. D. R., and Van Wassenhove, L. N. (2008). Product reuse economics in closed-loop supply chain research. Prod. Oper. Manage. 17, 483-496. doi: 10.3401/poms.1080.0051

Bag, S., Gupta, S., and Foropon, C. (2019). Examining the role of dynamic remanufacturing capability on supply chain resilience in circular economy. Manage. Decis. 57, 863-885. doi: 10.1108/MD-07-2018-0724

Barquet, A. P. B., de Oliveira, M. G., Amigo, C. R., Cunha, V. P., and Rozenfeld, H. (2013). Employing the business model concept to support the adoption of product-service systems (PSS). Ind. Mark. Manage. 42, 693-704. doi: 10.1016/j.indmarman.2013.05.003

Bloching, B., Leutinger, P., Oltmanns, T., Rossbach, C., Schlick, T., Remane, G., et al. (2015). Die Digitale Transformation der Industrie. Roland Berger Strategy Consultants.

Bocken, N., Strupeit, L., Whalen, K., and Nußholz, J. (2019). A review and evaluation of circular business model innovation tools. Sustainability 11:2210. doi: $10.3390 /$ su11082210

Böhm, M., Weking, J., Fortunat, F., Müller, S., Welpe, I., and Krcmar, H. (2017). "The business model DNA: towards an approach for predicting business model succes," in Proceedings der 13. Internationalen Tagung Wirtschaftsinformatik, 1006-1020.

Bovensiepen, G., Rumpff, S., Raimund, S., and Bender, S. (2016). Customer Centricity - den Kunden im Visier. Pricewaterhouse Coopers.

British Standards Institution (2009). Design for Manufacture, Assembly, Disassembly and End-of-Life Processing (MADE) Part 2.

Buck, D., Buehler, R., Happ, P., Rawls, B., Payton, C., and Borecki, N. (2013). Are bikeshare users different from regular cyclists? Transportation Res. Rec. J Transportation Res. Board 2387, 112-119. doi: 10.3141/2387-13

\section{AUTHOR CONTRIBUTIONS}

CK: abstract and results service models. CK and JG: introduction and discussion. JK: methodology. JG: results sales models. CK, JK, JG, and FD: review and editing the draft. All authors have read and agreed to the published version of the manuscript.

\section{FUNDING}

This study was one of the outcomes of the research project AddRE-Mo (Value Preservation Scenarios for Urban Electromobility of Persons and Loads through Additive Manufacturing and Remanufacturing), which is part of the funding measure Resource Efficient Circular EconomyInnovative Product Cycles (ReziProK) and was funded by the German Federal Ministry of Education and Research (BMBF) with a Grant No 033R234E.

Bungard, P. (Hrsg.) (2018). CSR und Geschäftsmodelle: Auf dem Weg zum zeitgemäßen Wirtschaften. Berlin: Springer Gabler. doi: 10.1007/978-3-66252882-2

Chierici, E., and Copani, G. (2016). Remanufacturing with upgrade PSS for new sustainable business models. Procedia CIRP 47, 531-536. doi: 10.1016/j.procir.2016.03.055

Collan, M., and Michelsen, K.-E. (Hrsg.) (2020). Technical, Economic and Societal Effects of Manufacturing 4.0: Automation, Adaption and Manufacturing in Finland and Beyond. Cham: Springer International Publishing. doi: 10.1007/978-3-030-46103-4

Colledani, M., and Battaiia, O. (2016). A decision support system to manage the quality of End-of-Life products in disassembly systems. CIRP Ann. Manuf. Tech. 65, 41-44. doi: 10.1016/j.cirp.2016.04.121

Commerzbank, A. G. (2017). Digitalisierung im Mittelstand (Frankfurt am Main). Available online at: https://media.events.commerzbank.de/media/ projektmedien/e_mail/2017/newsletter/Digitalisierung_im_Mittelstand.pdf (accessed November 15, 2021).

de Brito, M., and Peters, F. H. J. (2010). "Scooter Leasing: A cradle-to-cradle sound strategy?" in 12th World Conference on Transport Research (WCTR), Lissabon, Portugal. Available online at: https:/www.researchgate.net/publication/ 45412541_Scooter_Leasing_A_Cradle-to-Cradle_Sound_Strategy (accessed November 15, 2021).

Dias, A. S., Kim, H., Sivakumar, P. K., Liu, Z. C., and Zhang, H. C. (2013). "Life cycle assessment: a comparison of manufacturing and remanufacturing processes of a diesel engine," in Re-Engineering Manufacturing for Sustainability (1st Edn), eds A. Y. C. Nee, B. Song, and S. K. Ong (Springer), 675-678. doi: 10.1007/978-981-4451-48-2_110

DIHK (2017). Wachsende Herausforderungen treffen auf größeren Optimismus - das IHK-Unternehmensbarometer zur Digitalisierung. Deutscher Industrieund Handelskammertag.

Dircksen, M., and Feldmann, C. (2020). Holistic evaluation of the impacts of additive manufacturing on sustainability, distribution costs, and time in global supply chains. Transportation Res. Proc. 48, 2140-2165. doi: $10.1016 /$ j.trpro.2020.08.272

Disselkamp, M. (2005). Innovationsmanagement: Instrumente und Methoden zur Umsetzung im Unternehmen (1. Aufl). Gabler.

Dombrowski, U., Fochler, S., and Malorny, C. (Hrsg.) (2020). After Sales Service: Zukunftsfähig und Prozessorientiert Gestalten. Springer Vieweg. doi: 10.1007/978-3-662-62325-1

Feldmann, C. (2018). Innovative Geschäftsmodelle mit 3D-Druck. Band 2: Ein Leitfaden von der Idee zur Umsetzung (1. Auflage). Fachhochschule Münster, Münster School of Business, Institut für Prozessmanagement und Digitale Transformation (IPD). doi: 10.1007/978-3-658-25162-8_10 
Feldmann, C., Schulz, C., and Fernströning, S. (2019). Digitale GeschäftsmodellInnovationen mit 3D-Druck: Erfolgreich entwickeln und Umsetzen. Wiesbaden: Springer Gabler. doi: 10.1007/978-3-658-25162-8

Fishman, E. (2016). Bikeshare: a review of recent literature. Transp. Rev. 36, 92-113. doi: 10.1080/01441647.2015.1033036

Ford, S., and Despeisse, M. (2016). Additive manufacturing and sustainability: an exploratory study of the advantages and challenges. J. Clean. Prod. 137, 1573-1587. doi: 10.1016/j.jclepro.2016.04.150

Frankenberger, K., Weiblen, T., Csik, M., and Gassmann, O. (2013). The 4Iframework of business model innovation: a structured view on process phases and challenges. Int. J. Prod. Dev. 18, 249-273. doi: 10.1504/IJPD.2013.055012

Gassmann, O., and Frankenberger, K. (Hrsg.) (2016). "Geschäftsmodelle entwickeln: Von der Kunst zum Handwerk," in Geschäftsmodellinnovationen, eds P. Granig, E. Hartlieb, and D. Lingenhel (Wiesbaden: Springer Fachmedien Wiesbaden), 17-33. doi: 10.1007/978-3-658-08623-7_1

Gassmann, O., Frankenberger, K., and Choudury, M. (2021). Geschäftsmodelle entwickeln: $55+$ innovative Konzepte mit dem St. Galler Business Model Navigator (3., überarbeitete und erweiterte Auflage). Hanser. doi: $10.3139 / 9783446467620 . \mathrm{fm}$

Gassmann, O., Frankenberger, K., and Csik, M. (2013). "Revolutionizing the business model," in Management of the Fuzzy Front End of Innovation. doi: 10.1007/978-3-319-01056-4_7

Gauthier, C., and Gilomen, B. (2016). Business models for sustainability: energy efficiency in urban districts. Organ. Environ. 29, 124-144. doi: $10.1177 / 1086026615592931$

Gebhardt, A. (2016). Additive Fertigungsverfahren: Additive Manufacturing und 3D-Drucken für Prototyping-Tooling-Produktion (5., neu bearbeitete und erweiterte Auflage). Hanser. doi: 10.3139/9783446445390

Geissdoerfer, M., Pieroni, M. P. P., Pigosso, D. C. A., and Soufani, K. (2020). Circular business models: a review. J. Clean. Prod. 277:123741. doi: 10.1016/j.jclepro.2020.123741

Geissdoerfer, M., Vladimirova, D., and Evans, S. (2018). Sustainable business model innovation: a review. J. Clean. Prod. 198, 401-416. doi: 10.1016/j.jclepro.2018.06.240

Goedkoop, M. J., van Halen, C. J. G., te Riele, H. R. M., and Rommens, P. J. M. (1999). Product Service Systems, Ecological and Economic Basics. Available online at: https://www.researchgate.net/publication/293825611_Product_ Service_systems_Ecological_and_Economic_Basics (accessed November 15, 2021).

Guide, V. D. R., and Li, J. (2010). The potential for cannibalization of new products sales by remanufactured products. Decis. Sci. 41, 547-572. doi: $10.1111 / j .1540-5915.2010 .00280 . x$

Guide, V. D. R., and Wassenhove, L. N. V. (2009). The evolution of closedloop supply chain research. Oper. Res. 57, 10-18. doi: 10.1287/opre.1080. 0628

Günzel, F., and Holm, A. B. (2013). One size does not fit all - understanding the front-end and back-end of business model innovation. Int. J. Innov. Manage. 17:1340002. doi: $10.1142 / \$ 1363919613400021$

Häfner, C., Koller, J., Koop, C., and Klein, V. (2021). Zukunftstrend nachhaltige Elektrofahrräder? Erhebung zur Kreislaufwirtschaft in der Elektrofahrradbranche. Available online at: https://www.ipa.fraunhofer.de/ de/Publikationen/studien/zukunftstrend_nachhaltige_elektrofahrraeder.html (accessed November 15, 2021).

Hartwell, I., and Marco, J. (2016). Management of intellectual property uncertainty in a remanufacturing strategy for automotive energy storage systems. J. Remanufacturing 6:3. doi: 10.1186/s13243-016-0025-Z

Huang, Y., Qian, L., Soopramanien, D., and Tyfield, D. (2021). Buy, lease, or share? Consumer preferences for innovative business models in the market for electric vehicles. Technol. Forecasting Soc. Change 166:120639. doi: $10.1016 / j$.techfore.2021.120639

Husniah, H., Pasaribu, U. S., and Iskandar, B. P. (2021). Multi-period lease contract for remanufactured products. Alex. Eng. J. 60, 2279-2289. doi: 10.1016/j.aej.2020.12.013

Joyce, A., and Paquin, R. L. (2016). The triple layered business model canvas: a tool to design more sustainable business models. J. Cleaner Prod. 135, 1474-1486. doi: 10.1016/j.jclepro.2016.06.067

Kleylein-Feuerstein, J. (2020). Autarkie der Langzeitverfügbarkeit technischer Produkte mittels additiver Fertigung. Shaker Verlag.
Kock, A., Heising, W., and Gemünden, H. G. (2015). How ideation portfolio management influences front-end success: ideation portfolio management. $J$. Prod. Innov. Manage. 32, 539-555. doi: 10.1111/jpim.12217

Kohlhuber, M., Kage, M., and Karg, M. (2016). Additive Fertigung (acatech - Deutsche Akademie der Technikwissenschaften, Deutsche Akademie der Naturforscher Leopoldina, and Union der deutschen Akademien der Wissenschaften, Hrsg.).

Koller, J., Velte, C. J., Schötz, S., and Döpper, F. (2020). Customizing products through remanufacturing -ideation of a concept. Procedia Manuf. 43, 598-605. doi: 10.1016/j.promfg.2020.02.151

Koop, C., Koller, J., Große, J., and Klein, V. (2021). Kreislaufwirtschaft in der Elektrofahrradbranche: Untersuchung zur Refabrikation als Lösungsansatz für eine Kreislaufführung von Elektrofahrrädern. Müll Abfall 8:5. doi: 10.37307/j.1863-9763.2021.08.05

Lachmayer, R., Lippert, R. B., and Kaierle, S. (Hrsg.) (2018). Additive Serienfertigung: Erfolgsfaktoren und Handlungsfelder für die Anwendung. Springer Vieweg. doi: 10.1007/978-3-662-56463-9

Lange, U. (2017). Ressourceneffizienz durch Remanufacturing - Industrielle Aufarbeitung von Altteilen (Kurzanalyse, Nummer Nr. 18).

Lewandowski, M. (2016). Designing the business models for circular economytowards the conceptual framework. Sustainability 8:43. doi: 10.3390/su8010043

Li, Y., Jia, G., Cheng, Y., and Hu, Y. (2017). Additive manufacturing technology in spare parts supply chain: a comparative study. Int. J. Prod. Res. 55, 1498-1515. doi: 10.1080/00207543.2016.1231433

Liu, Z., Jiang, Q., Li, T., Dong, S., Yan, S., Zhang, H., et al. (2016). Environmental benefits of remanufacturing: a case study of cylinder heads remanufactured through laser cladding. J. Cleaner Prod. 133, 1027-1033. doi: $10.1016 /$ j.jclepro.2016.06.049

Ma, X., Yuan, Y., Van Oort, N., and Hoogendoorn, S. (2020). Bike-sharing systems' impact on modal shift: a case study in Delft, the Netherlands. J. Cleaner Prod. 259:120846. doi: 10.1016/j.jclepro.2020.120846

Magretta, J. (2002). Why business models matter. Harv. Bus. Rev. 80, 86-92. Available online at: https://hbr.org/2002/05/why-business-models- matter

Mansuy, J., Lebeau, P., and Macharis, C. (2021). "Towards a novel ideation tool for circular business model innovation," in Proceedings of the 6th International Conference on New Business Models (Halmstad), S. 354-363.

Matsumoto, M., Yang, S., Martinsen, K., and Kainuma, Y. (2016). Trends and research challenges in remanufacturing. Int. J. Precision Eng. Manuf. Green Technol. 3, 129-142. doi: 10.1007/s40684-016-0016-4

Merten, M. (2017). Diensträder: Steuerfallen können Hässlich Werden. Available online at: https://www.handelsblatt.com/finanzen/steuern-recht/steuern/ dienstraeder-steuerfallen-koennen-haesslich-werden/19857702.html?ticket= ST-1076720-qcIbWOahrdiGOPDfdjNz-ap5 (accessed November 15, 2021).

Montero, J., Atzberger, A., Schmidt, T. S., Bleckmann, M., Holtmannspötter, J., and Paetzold, K. (2020). "Anwendung agiler Entwicklungsprinzipien für die Herstellung von Ersatzteilen mit additiven Fertigungsverfahren," in Konstruktion für die Additive Fertigung 2018, eds R. Lachmayer, R. B. Lippert, and S. Kaierle (Berlin; Heidelberg: Springer), 209-226. doi: 10.1007/978-3-662-59058-4_12

Moro, S. R., Imhof, A. C., Fettermann, D. C., and Cauchick-Miguel, P. A. (2018). Barriers to bicycle sharing systems implementation: analysis of two unsuccessful PSS. Procedia CIRP 73, 191-196. doi: 10.1016/j.procir.2018. 03.312

Nasr, N., Peck, D., Badalucco, L., and Franconi, A. (2019). Design for Sharing, Incentivizing Circular Bike Sharing Systems. Rivista di Studi sulla Sostenibilita.

Nasr, N., and Thurston, M. (2006). Remanufacturing: A Key Enabler to Sustainable Product Systems.

Nußholz, J. L. K. (2017). Circular Business Models: Defining a Concept and Framing an Emerging Research Field. Sustainability 9:1810. doi: $10.3390 / \mathrm{su} 9101810$

Osterwalder, A. (2004). The Business Model Ontology - A Proposition in a Design Science Approach.

Osterwalder, A., Pigneur, Y., Bernarda, G., and Smith, A. (2014). Value Proposition Design: How to Create Products and Services Customers Want. John Wiley and Sons.

Osterwalder, A., Pigneur, Y., and Clark, T. (2010). Business Model Generation: A Handbook for Visionaries, Game Changers, and Challengers. Hoboken, NJ: Wiley. 
Östlin, J., Sundin, E., and Björkman, M. (2008). Importance of closed-loop supply chain relationships for product remanufacturing. Int. J. Prod. Econ. 115, 336-348. doi: 10.1016/j.ijpe.2008.02.020

Parker, D., Riley, K., Robinson, S., Symington, H., Tewson, J., Jansson, K., et al. (2015). Remanufacturing Market Study. Available onine at: https://www. remanufacturing.eu/assets/pdfs/remanufacturing-market-study.pdf (accessed November 15, 2021).

Porter, M. E. (2014). Wettbewerbsvorteile: Spitzenleistungen erreichen und behaupten $=($ Competitive Advantage) (8., durchges. Aufl). Campus-Verl.

Rieg, F., and Steinhilper, R. (Hrsg.) (2018). Handbuch Konstruktion (2., aktualisierte Auflage). Hanser. doi: 10.3139/9783446456198.fm

Rürup, B., and Jung, S. (2021). Digitalisierung: chancen auf neues wachstum," in CSR und Digitalisierung, eds A. Hildebrandt and W. Landhäußer (Berlin; Heidelberg: Springer), 13-30. doi: 10.1007/978-3-662-61836-3_2

Russell, J., and Nasr, N. (2020). "Value-Retention Processes within the Circular Economy," in Fundamentals of Remanufacturing: Operations, Engineering and Logistics, $1^{\text {st }} E d n$, ed N. Nasr (Hoboken, NJ: John Wiley and Sons, Inc; Scrivener Publishing LLC), 1-30. doi: 10.1002/9781119664383.ch1

Scholl, G., Maike, G., Magnus, G., and Brumbauer, T. (2013). Alternative Nutzungskonzepte - Sharing, Leasing und Wiederverwendung. Vertiefungsanalyse $1 \mathrm{im}$ Projekt Ressourcenpolitik: Analyse der ressourcenpolitischen Debatte und Entwicklung von Politikoptionen (PolRess). Available online at: https://refubium.fu-berlin.de/bitstream/handle/fub188/ 20194/PoLRess_AP2-Vertiefungsanalyse_alternativexNutzungskonzepte_ FINAL.pdf;jsessionid $\$=\$$ D6CC9F5E6D32FB1FAD139E14287B13C0? sequence $\$=\$ 1$ (accessed November 15, 2021).

Schulz, C., Feldmann, C., and Kapell, R. (2018). Innovative Geschäftsmodelle mit 3D-Druck. Band 1: Handlungsfelder für KMU / Colin Schulz, Carsten Feldmann, Rica Kapell (1. Auflage). Fachhochschule Münster, Münster School of Business, Institut für Prozessmanagement und Digitale Transformation (IPD). doi: 10.1007/978-3-658-25162-8_6

Steeneck, D. W., and Sarin, S. C. (2018). Product design for leased products under remanufacturing. Int. J. Prod. Econ. 202, 132-144. doi: 10.1016/j.ijpe.2018.04.025

Steinhilper, R. (1999). Produktrecycling: Vielfachnutzen durch Mehrfachnutzung. Fraunhofer-IRB-Verlag.

Steinhöfel, E., Kohl, H., and Orth, R. (2016). "Business model innovation: a comparative analysis," in Proceedings of the 11th European Conference on Innovation and Enrepreneurship, Jyväskylä, Finland, 15-16 (S. 770-780).

Stern, T., and Jaberg, H. (2007). Erfolgreiches Innovationsmanagement: Erfolgsfaktoren, Grundmuster, Fallbeispiele (3., überarb. u. erw. Aufl). Gabler. doi: 10.1007/978-3-8349-9546-9

Sun, S. (2021). How does the collaborative economy advance better product lifetimes? A case study of free-floating bike sharing. Sustainability 13:1434. doi: 10.3390/su13031434

Täuscher, K., and Abdelkafi, N. (2017). Visual tools for business model innovation: recommendations from a cognitive perspective. Creativity Innov. Manage. 26, 160-174. doi: 10.1111/caim.12208
Tukker, A. (2004). Eight types of product-service system: eight ways to sustainability? Experiences from SusProNet. Bus. Strategy Environ. 13, 246-260. doi: 10.1002/bse.414

Tukker, A. (2015). Product services for a resource-efficient and circular economy - a review. J. Cleaner Prod. 97, 76-91. doi: 10.1016/j.jclepro.2013.11.049

Verein Deutscher Ingenieure (2014). Additive Fertigungsverfahren. Grundlagen, Begriffe, Verfahrensbeschreibungen (Nummer 3405). Beuth Verlag.

Verein Deutscher Ingenieure. (2002). VDI-Richtlinie 2243: Recyclingorientierte Produktentwicklung. Beuth Verlag.

von Ahsen, A., Kuchenbuch, A., and Heesen, M. (2010). Bewertung von Innovationen im Mittelstand. Heidelberg: Springer. doi: 10.1007/978-3-642-01700-1

Walther, G. (2010). Nachhaltige Wertschöpfungsnetzwerke: Überbetriebliche Planung und Steuerung von Stoffströmen entlang des Produktlebenszyklus (1. Aufl). Gabler.

Westkämper, E., and Warnecke, H.-J. (2010). Einführung in die Fertigungstechnik. doi: 10.1007/978-3-8348-9798-5

Williams, A. (2007). Product service systems in the automobile industry: contribution to system innovation? J. Cleaner Prod. 15, 1093-1103. doi: 10.1016/j.jclepro.2006.05.034

Winter, K. (2009). Wirkung von Limited Editions für Marken: Theoretische Überlegungen und empirische Überprüfung (1. Aufl). Gabler.

Wrede, I. (2021). Ausverkauft: Der unglaubliche Fahrrad-Boom. Available online at: https://www.dw.com/de/ausverkauft-der-unglaubliche-fahrrad-boom/a53898806 (accessed November 15, 2021).

Zweirad-Industrie-Verband. (2021). Zahlen - Daten - Fakten zum Fahrradmarkt in Deutschland 2020 [Wirtschaftspressekonferenz am 10.März 2021 in Berlin]. Available online at: https://www.ziv-zweirad.de/fileadmin/redakteure/ Downloads/Marktdaten/PM_2021_10.03._ZIV-Praesentation_10.03.2021_ mit_Text.pdf (accessed November 15, 2021).

Conflict of Interest: The authors declare that the research was conducted in the absence of any commercial or financial relationships that could be construed as a potential conflict of interest.

Publisher's Note: All claims expressed in this article are solely those of the authors and do not necessarily represent those of their affiliated organizations, or those of the publisher, the editors and the reviewers. Any product that may be evaluated in this article, or claim that may be made by its manufacturer, is not guaranteed or endorsed by the publisher.

Copyright (C) 2021 Koop, Grosse Erdmann, Koller and Döpper. This is an open-access article distributed under the terms of the Creative Commons Attribution License (CC $B Y)$. The use, distribution or reproduction in other forums is permitted, provided the original author(s) and the copyright owner(s) are credited and that the original publication in this journal is cited, in accordance with accepted academic practice. No use, distribution or reproduction is permitted which does not comply with these terms. 